\title{
Factsheet: Youth in India: Situation and needs-Key indicators, 2006-2007: Rajasthan
}

International Institute for Population Sciences (IIPS)

Follow this and additional works at: https://knowledgecommons.popcouncil.org/departments_sbsr-pgy

Part of the Demography, Population, and Ecology Commons, Family, Life Course, and Society Commons, International Public Health Commons, and the Medicine and Health Commons How does access to this work benefit you? Let us know!

\section{Recommended Citation}

"Factsheet: Youth in India: Situation and needs-Key indicators, 2006-2007: Rajasthan." New Delhi: Population Council, 2008. 


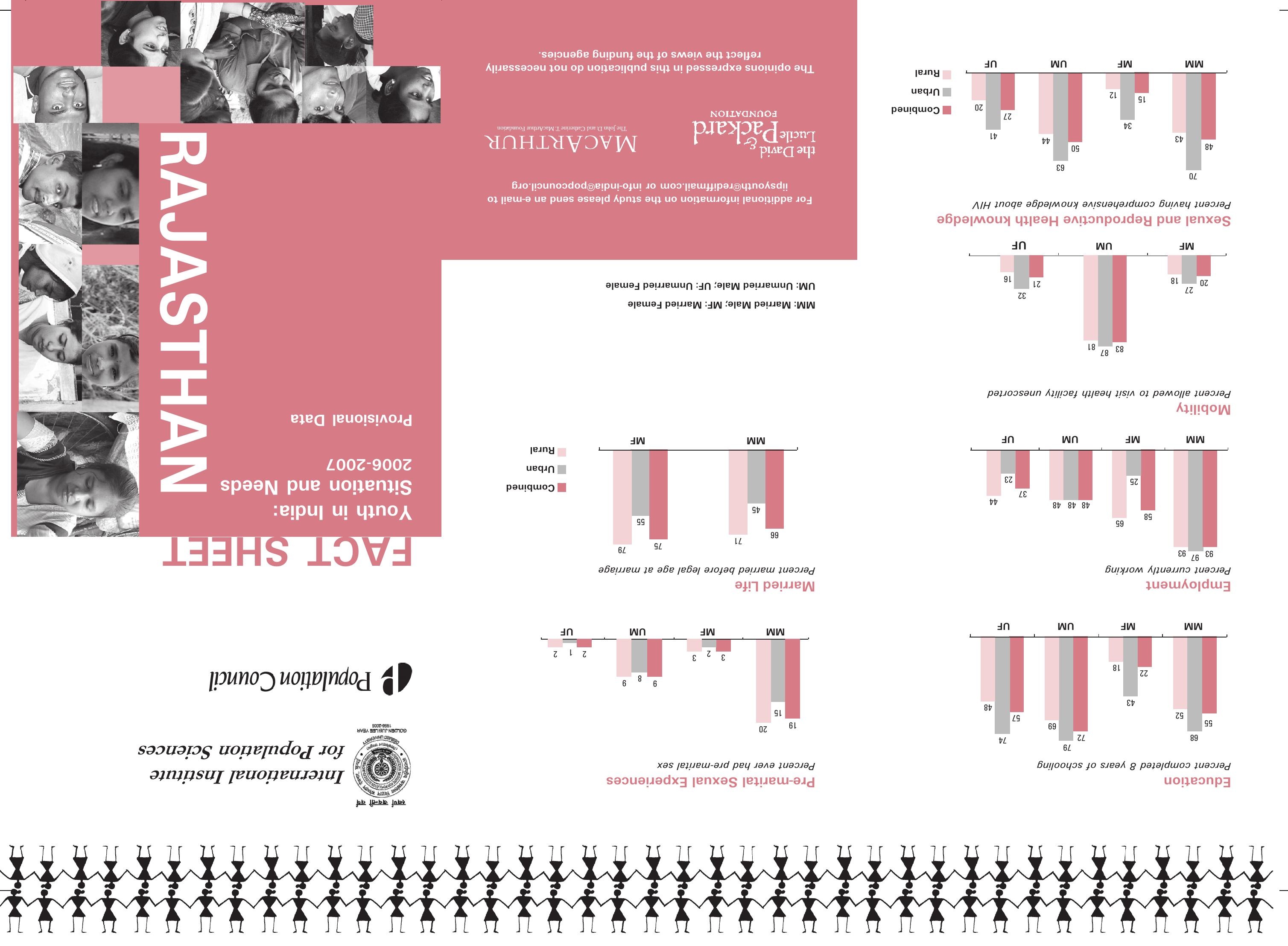

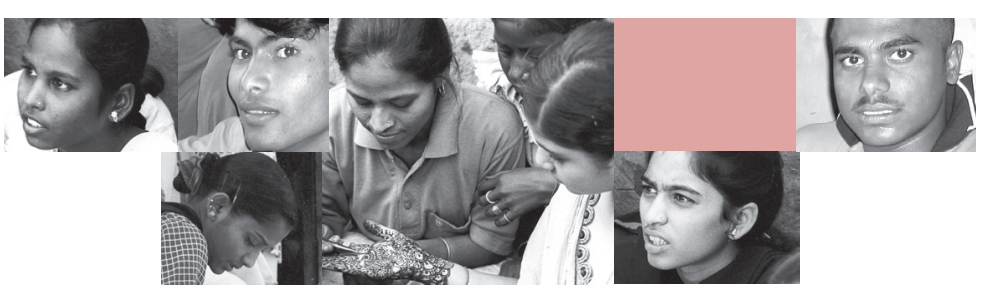

The main goal of the Youth in India: Situation and Needs Study 2006/7 is to provide information on the situation of youth and the life choices available to them on a broad range of sexual and reproductive health issues, including both behaviors and their antecedents, through a population-based study. Findings are expected to inform evidence-based programming to address the health and other needs of young people. This sub-national study has been undertaken in six states, namely, Andhra Pradesh, Bihar, Jharkhand, Maharashtra, Rajasthan and Tamil Nadu. Specific objectives are to:

(1) identify key transitions facing youth, including education and livelihood opportunities and experiences; (2) provide evidence at state level on the magnitude and patterns of sexual and

reproductive practices in and outside of marriage, and related knowledge, decision-making and attitude; ( 3 ) identify the key factors underlying young people's sexual and reproductive health, knowledge, attitudes and life choices.

The study design involves pre- and post-survey qualitative phases and a survey of unmarried youth and married females aged 15-24 and married males aged 15-29 (in view of the paucity of married males aged 15-24), residing in rural and urban areas of each state. The International Institute for Population Sciences (IIPS), Mumbai, is implementing the study in collaboration with the Population Council, New Delhi, with financial support from the Packard and MacArthur Foundations.

Fieldwork for Rajasthan was conducted during March-November 2007. This fact sheet presents selected key indicators for the state.

\section{Sample size and response rate}

\begin{tabular}{lrrrrrr} 
& \multicolumn{3}{c}{ Number selected for interview } & \multicolumn{3}{c}{ Response rate } \\
& Combined & Urban & Rural & Combined & Urban & Rural \\
\hline Households & 31064 & 10511 & 20553 & 99.2 & 98.9 & 99.4 \\
Married males (age 15-29) & 2045 & 678 & 1367 & 92.2 & 93.1 & 91.8 \\
Married females (age 15-24) & 2914 & 1158 & 1756 & 89.3 & 89.6 & 89.1 \\
Unmarried males (age 15-24) & 2256 & 1043 & 1213 & 94.4 & 94.6 & 94.1 \\
Unmarried females (age 15-24) & 3599 & 1529 & 2070 & 94.0 & 93.9 & 94.1 \\
\hline
\end{tabular}

\section{Population and household profile}

\begin{tabular}{lccc} 
& Combined & Urban & Rural \\
\hline $\begin{array}{l}\text { Population age 6+ that is literate (\%) } \\
\text { Households by residence (\%) } \\
\text { Mean household size }\end{array}$ & 60.5 & 77.2 & 55.5 \\
$\begin{array}{l}\text { Percentage of households that: } \\
\text { Have electricity }\end{array}$ & 100.0 & 22.7 & 77.3 \\
Using drinking water from piped water/ & 66.4 & 5.3 & 5.4 \\
$\quad$ hand pump/ covered well (own / public) & & 94.6 & 58.1 \\
Have access to a toilet facility & 83.1 & 98.2 & 78.7 \\
Live in a pucca house & 31.9 & 81.6 & 17.3 \\
Have a motorized vehicle & 60.3 & 90.1 & 51.6 \\
Have a television & 22.3 & 45.2 & 15.6 \\
Own agricultural land & 35.9 & 75.7 & 24.3 \\
\hline
\end{tabular}

\section{Percentage of youth in surveyed population}

\begin{tabular}{lccc} 
& Combined & Urban & Rural \\
\hline Married males (age 15-29) & 6.0 & 4.8 & 6.3 \\
Married females (age 15-24) & 5.3 & 4.0 & 5.7 \\
Unmarried males (age 15-24) & 6.6 & 8.9 & 6.0 \\
Unmarried females (age 15-24) & 3.9 & 5.9 & 3.4
\end{tabular}

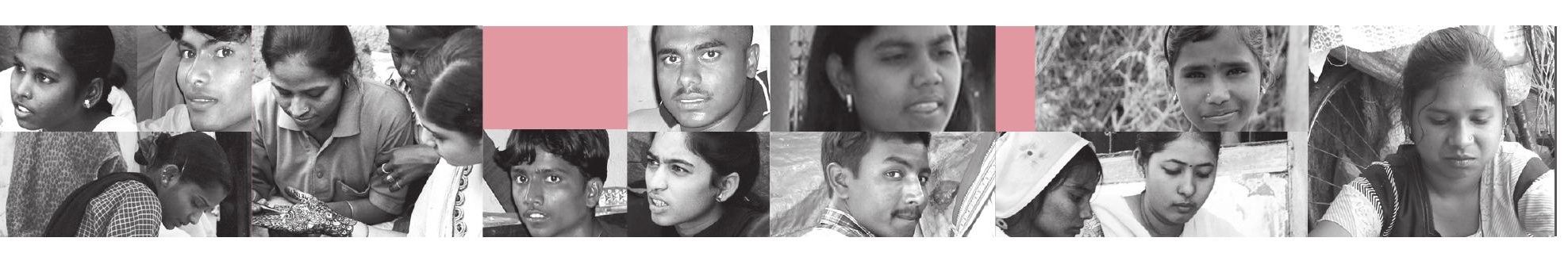

